\title{
Description of a new monospecific genus of South African Trichiina, with a key to the related genera (Coleoptera: Scarabaeidae)
}

\author{
Enrico RICCHIARDI \\ Corso A. Tassoni 79/4, 10143 Torino, Italy. \\ E-mail: alericor@,fastwebnet.it \\ urn:1sid:zoobank.org:author:F09BCF76-35DE-4821-91C4-EEDC5114810A
}

\begin{abstract}
A new monospecific genus, Pseudostegopterus gen. nov., endemic to the northwestern region of South Africa, is erected. The type species is described as Pseudospegopterus melonthinoides sp. nov. and is currently known only from male specimens. A provisional dichotomic key of the African Trichiina genera is also provided, in order to facilitate the identification of male specimens to the genus level.
\end{abstract}

Key words. Cetoniinae, Pseudostegopterus, Afrotropical Region, new genus, new species.

Ricchiardi E. 2015. Description of a new monospecific genus of South African Trichiina, with a key to the related genera (Coleoptera: Scarabaeidae). European Journal of Taxonomy 159: 1-6. http://dx.doi.org/10.5852/ejt.2015.159

\section{Introduction}

The number of described Trichiina species (sensu Smith et al. 2006) endemic to South Africa has increased substantially during the last two decades (Evans 1987; Ricchiardi 1997, 1998, 1999, 2000; Ricchiardi et al. 2004, 2008; Sipek et al. 2012; Ricchiardi \& Perissinotto 2013, 2014) and currently ranges around 40 . These species are grouped into nine genera, with three of them regarded as tropical intruders and represented in South Africa by one single species each. The biodiversity richness of this country is well established, but many taxa remain as yet underscribed, among them several Trichiina.

While undertaking a close analysis of the specimens preserved at the Iziko South African Museum (ISAM) in Cape Town and in my private collection, I have recently identified a series of eight males belonging to an undescribed species, which superficially resembles members of the genus Stegopterus Burmeister \& Schaum, 1840. However, on closer scrutiny it is clear that a new genus is involved. Both genus and species are hereby described as Pseudostegopterus gen. nov. and P. melolonthinoides gen. et sp. nov.

The species is currently known only from the two type localities of Elands Bay and Pella Mission in the Western Cape, South Africa.

\section{Material and methods}

The following abbreviations are used to denote the housing location of the study material:

$\mathrm{ERC}=$ Enrico Ricchiardi collection, Torino, Italy

ISAM = Iziko South African Museum, Cape Town, South Africa 
The specimen length was measured between the apex of the pygidium and the anterior margin of the pronotum. The specimen width is the maximum elytron width. The clypeus length was measured laterally, between the frontal margin and the antennal basal attachment.

Photographs were taken with a Nikon Coolpix P7700, sometimes attached to one of the eyepieces of a Wild dissecting microscope. Photographs were processed with photo stacking software (Zerene Stacker - Version 1.04 Build T201411272115, http://www.zerenesystems.com [accessed 13 Nov. 2015]). Finally, backgrounds were removed from photos using GIMP 2.8.14, in order to increase contrast.

\title{
Results
}

\author{
Class Insecta \\ Order Coleoptera \\ Superfamily Scarabaeoidea Latreille, 1802 \\ Family Scarabaeidae Latreille, 1802 \\ Subfamily Cetoniinae Leach, 1815 \\ Tribe Trichiini Fleming, 1821 \\ Subtribe Trichiina Fleming, 1821
}

\section{Discussion}

This work is part of a series of studies aimed at identifying and clarifying the composition and morphological relations of the exceptionally diverse South African Trichiina. The phylogenetic relationships among the Trichiina of South Africa and those occurring in other parts of the continent are yet to be investigated and in need of further species descriptions and better definition of the genera. As a contribution to the understanding of the morphological relationship between the South African genera of Trichiina an updated dichotomic key is here proposed.

\section{Preliminary key to South African Trichiina genera}

1. Abdominal tergites not covered by elytra in dorsal view .................. Calometopus Blanchard, 1850

- Abdominal tergites covered by elytra in dorsal view ... 2

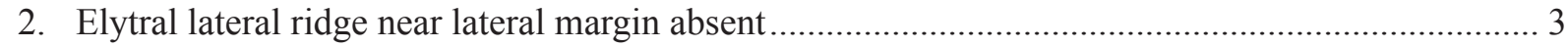

- Elytral lateral ridge present on most of lateral margin .................................................................... 4

3. Posterior pronotal corners widely rounded; mesosternal process present, but not visible in side view Myodermum Burmeister \& Schaum, 1840

- Posterior pronotal corners rounded or angled; mesosternal process absent .Diploa Kolbe, 1892

4. First metatarsal segment longer than second 5

- First metatarsal segment approximately as long as second

5. Pronotum length $>$ than 0.5 times elytral length; body large (length $20.3 \mathrm{~mm}$, width $11.0 \mathrm{~mm}$; glabrous, slightly shiny, black.

Camapterus Ricchiardi, 2000

- Pronotum length < than 0.5 times elytral length; body smaller, orange-red, but female often black or dark brown

6. Clypeus as wide as long.

- Clypeus wider than long. Posterior pronotal margin not emarginate 
7. Pronotum covered with very scattered setae (even if locally dense); female with normal wings....... Stripsipher Gory \& Percheron, 1833

- Pronotum covered with dense, long setae; male elytra light brown; female smaller, completely black or dark brown, brachypterous Eriopeltastes Burmeister \& Schaum, 1840

8. Metatibial apex modified 9

- Metatibia apex unmodified 10

9. Metatibial apex of male much longer than single metatibial spur; female metatibial apices truncate with two spurs. Brachagenius Kraatz, 1890

- Metatibial apex slightly pronouced in males, truncate in females, with two spurs

Elpidus Péringuey, 1907

10. Metafemura enlarged (maximum width larger than 0.5 its length); length of protarsal claws $>0.8$ that of last tarsal segment

Pseudostegopterus gen. nov.

- Metafemora slender (width less than 0.25 its length); length of protarsal claws at least 0.7 that of last tarsal segment Stegopterus Burmeister \& Schaum, 1840

\author{
Genus Pseudostegopterus gen. nov. \\ urn:1sid:zoobank.org:act:3FEB8498-B2A1-4136-904A-7EB7F37CE568
}

\title{
Type species
}

Pseudostegopterus melolonthinoides gen. et sp. nov.

\section{Diagnosis}

This new genus differs from all other Trichiini genera occurring in South Africa by the following combination of diagnostic characters: 1) The eye-canthus covers about $1 / 2$ of the ocular hemisphere; 2) the frons and vertex are covered with thick, long, inclined, testaceous setae; 3 ) the length of the pronotum is $<0.5$ times that of the elytra; 4 ) the posterior pronotal margin does not exhibit any ridge centrally; 5) the pronotal surface is generally covered with thick, long, inclined, testaceous setae; 6) the pronotal posterior corners are obtuse; 7) the elytral apex is rounded; 8) the elytral lateral ridge is visible on the entire lateral border; 9) the elytra cover the entire pygidium, except its very apex; 10) the length of protarsal claws is $0.70-0.90$ times that of the last tarsomere; 11) the mesotibia are slightly curved outwardly; 12) the metatibia exhibits two spurs; 13) the first metatarsal segment is as long as the second or shorter; 14) the metatibial apex is strongly enlarged; 15) the internal corner of the metatibial apex is deprived of long spines; 16) the mesosternal process is absent; 17) the metafemur width is $0.4-0.45$ times its length; 18) the males are fully winged.

\section{Etymology}

The name comes from its superficial resemblance to some representatives of the genus Stegopterus Burmeister \& Schaum, 1840.

Pseudostegopterus melolonthinoides sp. nov. urn:1sid:zoobank.org:act:42397679-9840-4330-AEDD-A9EE3CDD955B

Fig. 1

\section{Etymology}

While very similar to the smaller species of the genus Stegopterus, this species also resembles in color and shape a small Melolonthinae. 


\section{Type material}

\section{Holotype}

REPUBLIC OF SOUTH AFRICA: § (ISAM), Western Cape, Leipoldtville, Eland's Bay (32॰18’48” S, $18^{\circ} 21^{\prime} 00^{\prime \prime}$ E), Oct. 1947, Museum Expedition (SAM-CO-A043595).

\section{Paratypes}

REPUBLIC OF SOUTH AFRICA: 6 $ぇ$ (ISAM), same data as the holotype (but without SAM number); 1 ○ (ERC), Western Cape, Pella Mission (3337’30” S, 18³7’30” E), 14 Aug. 1947, N.J. Duke legit.

\section{Description}

\section{Holotype}

MEASUREMENTs. Length: $10.1 \mathrm{~mm}$; width: $5.4 \mathrm{~mm}$.

HEAD. Clypeus black, margins reflexed (Fig. 1C), anterior margin not sinuate, covered with thick, large punctures and long, recumbent, testaceous setae; vertex and frons black.

Antennae. Brown, with three lamellae, darkening at apex, slightly curved, about 2.0 times the length of clypeus.

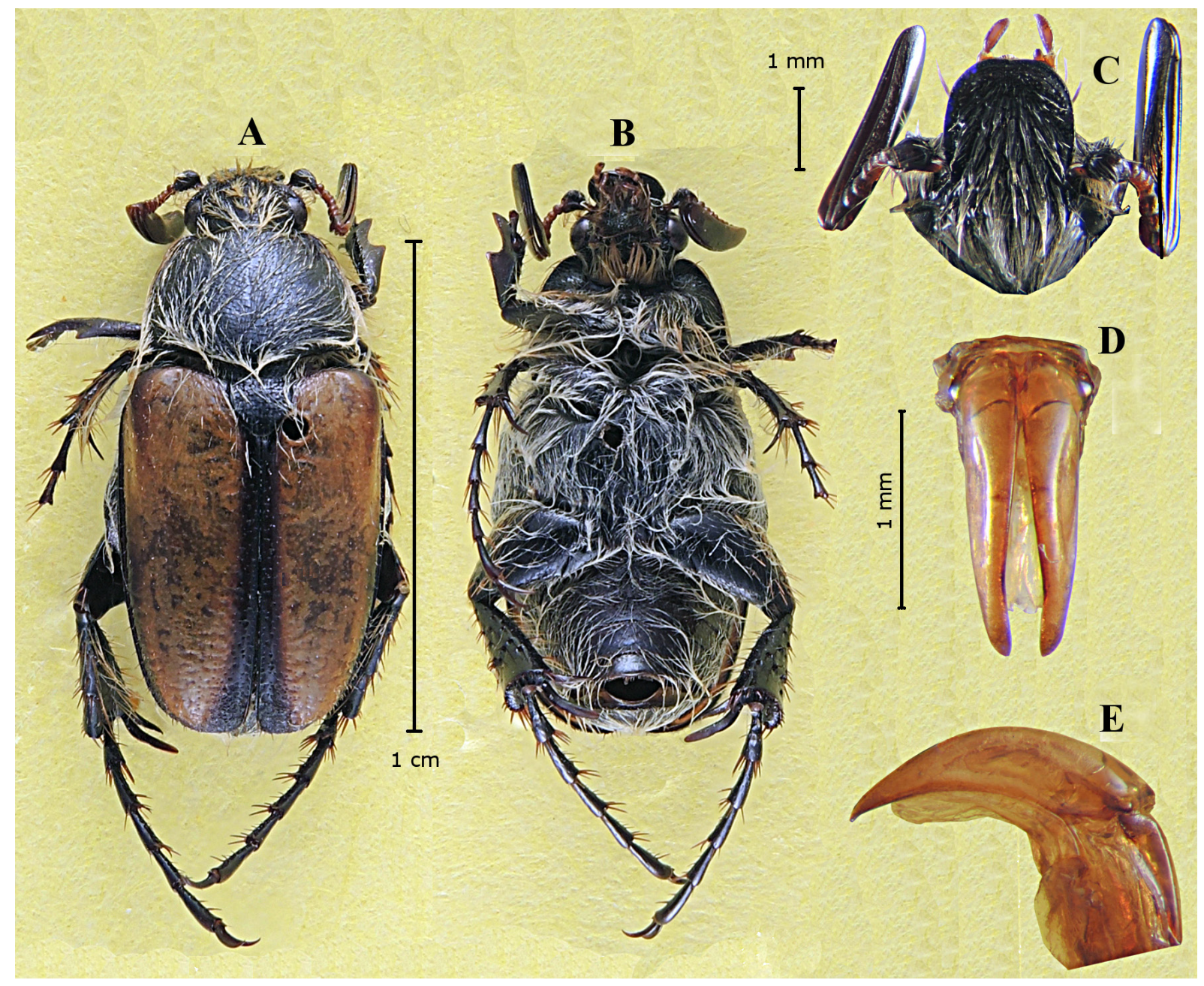

Fig. 1. Pseudostegopterus melolonthinoides gen. et sp. nov. Holotype, $ð$ (ISAM). A. Dorsal habitus. B. Ventral view. C. Head. D. Parameres, frontal view. E. Parameres, lateral view. 
Pronotum. Black, slightly shiny and rugulose, wider than long; anterior angles rounded, posterior acute, with slightly rounded tip; posterior margin without carina; surface covered with thick, long, reclining, testaceous setae.

Scutellum. Black, slightly shiny, triangular, as long as wide, apex slightly rounded; covered with scattered, rounded punctures.

ELYTRON. Mostly fulvous, transparent, glabrous, with a large black stripe along the suturae, larger at elytral apex; both striae and interstriae effaced; apicosutural angle rounded; sutural half of elytral apex scabrous.

AвDOMEN. Sternites black, shiny; covered with reclining, long, testaceous setae, becoming glabrous and matt on anal sternite; tergites black, covered with same setae as sternites.

Propygidium. Black, not visible, covered by elytron.

Pygidium. Black, rugulose, longer than wide, triangular, with apex rounded; covered with scattered, long, reclining, light testaceous setae.

PROTiBiA. Brown, glabrous, shiny, with two robust teeth on external margin.

MESOTIBIA. Black, slightly curved outwardly, with strong tooth at middle of external margin; proximal half covered with scattered, long, reddish, bristles; apex strongly enlarged; mesofemur black, shiny, covered with testaceous, reclined setae.

MetaTiBia. Black, shiny, with apex strongly enlarged; covered with scattered, long, reddish, bristles; metatarsomeres black, twice as long as metatibia (claws included); first segment about as long as second; spurs long, with apex rounded, especially on ventral one; dorsal spur 1.2 times longer than ventral and arcuate; metafemur enlarged, width 0.5 times its length.

\section{Remarks}

The female is unknown.

\section{Type series variability}

Some paratypes have darker elytra and/or scattered instead of dense setae on head and pronotum, which does not seem to represent simply wear and tear due to age.

\section{Distribution}

The single species belonging to this new genus is known from two places in the Western Cape Province. These two localities are especially relevant, as they are part of a unique biome, the fynbos, which is seriously threatened by climate change and land use.

\section{Acknowledgements}

I thank Dawn Larsen and Simon van Noort of ISAM (Cape Town) and Renzo Perissinotto of the Nelson Mandela Metropolitan University (Port Elizabeth) for kindly organizing the loan of material for this study.

\section{References}

Evans A. 1987. new species of the genus Brachagenius Kraatz (= Xiphoscelidus Peringuey syn. nov.) with notes on the synonymy of Elpidus hopei (Burmeister) (Coleoptera: Scarabaeidae: Trichiinae). Journal of the entomological Society of Southern Africa 50 (2): 351-356 
Ricchiardi E. 1997. Notes on South African Trichiini. On the genus Eriopeltastes Burmeister \& Schaum, 1840, with description of three new species (Coleoptera: Cetoniidae: Trichiinae). Elytron 11: 121-132.

Ricchiardi E. 1998. Notes for the revision of the genus Stripsipher Gory \& Percheron, 1833, with descriptions of four new species (Coleoptera, Cetoniidae, Trichiinae, Trichiini). Mitteilungen der Münchner Entomologischen Gesellschaft 88: 45-64.

Ricchiardi E. 1999. Description of three new species and the brachypterous females of the genus Eriopeltastes Burmeister \& Schaum, 1840 (=Diploeida Péringuey, 1907), (Coleoptera: Cetoniidae: Trichiinae). Elytron 11: 133-147.

Ricchiardi E. 2000. Camapterus, a new brachypterous Trichiini genus from South Africa (Coleoptera, Cetoniidae, Trichiinae). Elytron 14: 201-206.

Ricchiardi E., Perissinotto R. \& Clennell L. 2004. Parapeltastes, a new subgenus of Eriopeltastes Burmeister \& Schaum (1840) from South Africa, with description of a new species (Coleoptera, Cetoniidae, Trichiinae). Lambillionea 114: 223-229.

Ricchiardi E., Perissinotto R. \& Clennell L. 2008. Taxonomic revision of the South African genus Stripsipher Gory \& Percheron, 1833, with descriptions of four new species (Coleoptera, Cetoniidae, Trichiinae). Bollettino della Società Entomologica Italiana 140 (3): 155-178.

Ricchiardi E. \& Perissinotto R. 2013. Description and ecology of a new species of Eriopeltastes Burmeister \& Schaum 1840, from KwaZulu-Natal (South Africa). Zootaxa 3630 (2): 379-384. http:// dx.doi.org/10.11646/zootaxa.3630.2.12

Ricchiardi E. \& Perissinotto R. 2014. New species of Eriopeltastes Burmeister \& Schaum, 1840 (Coleoptera: Scarabaeidae: Cetoniinae: Trichiini), from South Africa. Zookeys 422: 103-113. http:// dx.doi.org/10.3897/zookeys.422.7830

Sipek P., Ricchiardi E. \& Perissinotto R. 2012. Immature stages and ecology of two species of the South African genus Stripsipher Gory \& Percheron, 1833 (Coleoptera: Scarabaeidae; Trichiinae). Zookeys 180: 19-40. http://dx.doi.org/10.3897/zookeys.180.2315

Smith A.B.T., Hawks D.C. \& Heraty J.M. 2006. An overview of the classification and evolution of the major scarab beetle clades (Coleoptera: Scarabaeoidea) based on preliminary molecular analyses. Papers in Entomology 121: 34-46.

Manuscript received: 2 September 2015

Manuscript accepted: 28 October 2015

Published on: 7 December 2015

Topic editor: Koen Martens

Desk editor: Charlotte Thionois

Printed versions of all papers are also deposited in the libraries of the institutes that are members of the EJT consortium: Muséum national d'Histoire naturelle, Paris, France; Botanic Garden Meise, Belgium; Royal Museum for Central Africa, Tervuren, Belgium; Natural History Museum, London, United Kingdom; Royal Belgian Institute of Natural Sciences, Brussels, Belgium; Natural History Museum of Denmark, Copenhagen, Denmark. 